\title{
The Hybrid Solid Oxide Fuel Cell (SOFC) and Gas Turbine (GT) Systems Steady State Modeling
}

\author{
Penyarat Chinda ${ }^{1, *}$ and Pascal Brault ${ }^{2}$ \\ ${ }^{1}$ Department of Mechanical Engineering Technology, College of Industrial Technology, \\ King Mongkut's University of Technology North Bangkok, 1518, Piboonsongkram Road, \\ Wong Sawang, Bangsue, Bangkok, 10800, Thailand \\ ${ }^{2}$ Groupe de Recherches sur l'Energétique des Milieux Ionisés (GREMI), UMR 6606 \\ CNRS-Université d'Orléans, BP6744, 45067, Orléans Cedex 2, France \\ *Corresponding author: penyaratc@kmutnb.ac.th, penyarat@yahoo.com \\ Tel. +66 (2) 9132500, Fax. +66 (2) 587-4350
}

\begin{abstract}
Solid Oxide Fuel Cells (SOFCs) are of great interest nowadays. The feature of SOFCs makes them suitable for hybrid systems because they work high operating temperature and when combined with conventional turbine power plants offer high cycle efficiencies. In this work a hybrid solid oxide fuel cell and gas turbine power system model is developed. Two models have been developed based on simple thermodynamic expressions. The simple models are used in the preliminary part of the study and a more realistic based on the performance maps. A comparative study of the simulated configurations, based on an energy analysis is used to perform a parametric study of the overall hybrid system efficiency. Some important observations are made by means of a sensitivity study of the whole cycle for the selected configuration. The results of the selected model were compared to an earlier model from an available literature.
\end{abstract}

Keywords: Cycle, Efficiency, Gas turbine, Hybrid, Solid Oxide Fuel Cell 


\section{Introduction}

Solid Oxide Fuel Cell (SOFC) is a highly efficient energy conversion device that transforms chemical energy to electrical energy and heat directly from fuels through electrochemical reactions at electrodes. The fuel can be natural gas, carbon monoxide, methanol, ethanol and hydrocarbon compounds as well as hydrogen. The SOFC can be used with a variety of power generation systems; both stationary power generators and auxiliary power sources in automobiles, in aircrafts or even in residential applications [1,2]. One cell consists of interconnected structures and a three - layered region composed of two ceramic electrodes (anode and cathode) separated by a dense ceramic electrolyte. SOFCs operate at high temperatures in the range 800 to $1000^{\circ} \mathrm{C}[1,2]$ and both atmospheric or elevated pressures and can utilize a variety of fuels. Oxygen ions formed at the cathode migrate through the ion - conducting electrolyte to the anode/electrolyte interface where they react with the fuel gases, producing water while releasing electrons that flow via an external circuit to the cathode/electrolyte interface. Unlike the low-temperature polymer fuel cell, SOFC operates at temperatures high enough to enable the direct reformation of natural gas. Flexibility in fuel utilization is an advantage of SOFCs over other types of fuel cells. Hydrocarbon fuels can be supplied directly to SOFCs without the need for pre - reforming processing $[1,2]$.

SOFC converts the hydrogen, reformed from the natural gas, electrochemically producing both electrical power and high-grade waste heat for combined heat and power (CHP) system. It has been demonstrated that SOFC can achieve 50\% net electrical efficiencies and have already been considered feasible for integration with multi-MW gas turbine engines to achieve higher electrical efficiency [3] . Siemens-Westinghouse Power Corporation developed the first advanced power system, which integrates a SOFC stack with the gas turbine engines. The pressurized ( 3 atm) system generates 220 $\mathrm{kW}$ of electrical power at a net electrical efficiency of 55\% [4]. During the decade many researchers have studied theoretical analysis and simulation of the possible configuration of hybrid system [5-11]. 
Depending upon the application, different models are available in the open literature and there are large differences in the level of details in the models presented. The lumped models that consider the fuel cells and the other components as the single lumped system, which reduces the complexity and computation time that have been center of attention and have been largely used for studies of different cycle configurations $[12,13]$ and to some extent for part-load studies [14 - 16]. As mentioned earlier, the great benefit of using lumped models is simplicity of the model development and short calculation time. A large amount of experimental data and mathematical relations exists for components such as compressors, turbines and heat exchangers, so these components can be modeled fairly accurately despite the lumped approach [17]. The lumped approach in SOFC models also facilitates uncomplicated changes between different geometries, as this only involves changes in geometry specific parameters. Accordingly, lumped models are also easier to adjust to experimental data. The disadvantage of lumped SOFC models is that they can only account for mean values of the parameters and it follows that more detailed investigation of the cell is needed for checking undesirable effects such as thermal cracking, coking or exceeding temperature limits locally [18]. This problem may be partly avoided by using a lumped model for system calculations, and a detailed model to test the validity of the results. Obviously, implementing a detailed SOFC model in the system model gives the most accurate results and this approach has been followed in [19]. The works in the previous study $[16,19]$ that they are developed the hybrid solid oxide fuel cell and gas turbine power generation system models based on first law of thermodynamics under steady state conditions. Both of them [16, 19] are for the small scale power generation systems. The heart of the model in the literature [16] is for a natural gas fed SOFC - GT power generation system and the system model in the literature [19] featuring focused on external pre-reforming and anode gas recirculation for the internal supply of steam. Based on the works in the literatures [16, 19], a hybrid solid oxide fuel cell and gas turbine power system model is mathematically developed to simulate the integrated power generation system 
under steady-state conditions, and the overall system performance has been also evaluated by the first law of thermodynamics. This present work aims for a 300 passenger commercial aircraft electrical power unit. Each component within the system is sized to meet the $440 \mathrm{~kW}$ input electrical load at sea level full power condition. The simple model is used in the preliminary step of the study and a more realistic one based on the performance maps is developed. A final necessary note is that future SOFC technology is projected for this application and specifically for this analysis. A typical timeline for a new aircraft development, especially a large civil transport, is on the order of 10 to 20 years. Systems analyses such as the following are required at this early stage and projections for both technology and the application are a challenging part of the design process. SOFC and SOFC-GT hybrid technology have made progress over the past decades but further maturity is necessary before an application such as this is feasible. Systems studies may extrapolate the capability of a technology, but the studies also quantify the necessary gains that must be made for feasibility. And the emphasis of this study is to reduce the reliance on experimental data for the performance prediction, and to extend the code developed previously for possible part-load simulation in the future.

\section{Mathematical modeling of SOFC - gas turbine hybrid system}

A gas turbine cycle is based on the Brayton cycle, which is a simple series of compression, combustion, and expansion processes. The main components of the cycle are a compressor, a combustor, and a gas turbine. The number of components is not limited to three as the cycle may consist of several compressors and turbines (expanders).

Figure 1 illustrates the basic schematic of a gas turbine engine. The ambient air is compressed and sent to the combustor. The constant pressure combustion takes place and the exhaust is sent to the turbine where power is extracted to drive the compressor and the generator. Heat exchangers can also be used to preheat the stream entering the combustion chamber. Gas turbine engines are generally used for power production falling in the range of few kilowatts to several megawatts and offer an 
electrical efficiency of $30-40 \%$. This can be further improved by adding a topping cycle to achieve efficiencies of up to $60 \%$. A gas turbine can be directly or indirectly connected to the SOFC. In an indirect integration, the combustor of the gas turbine is replaced with a heat exchanger in which air from the compressor is heated by the fuel cell exhaust and the SOFC can operate under atmospheric conditions. Although, it reduces the sealant requirement in the SOFC stack, the heat exchanger has to operate at very high temperatures and pressure differences. The material requirements in the indirect integration are really an issue and hence, it is not generally used.

Figure 2 shows a direct integration of a solid oxide fuel cell and a gas turbine system. As can be seen, the combustion chamber of the gas turbine engine has been replaced with an SOFC and an afterburner. The pressurized stream from the compressor goes into the SOFC. The exhaust from the SOFC goes to the afterburner and the resulting high temperature and pressure exhaust enters into the turbine. In this case, the SOFC operates at high pressure, which further improves its performance [2024]. Moreover, heat exchangers are added after the turbine exhaust to further utilize the waste heat in preheating of the streams entering the SOFC stack. The high-pressure operation of SOFC stack causes large pressure gradients between anode and cathode. This pressure imbalance needs to be avoided, due the brittleness of the SOFC materials, and good sealants are required to stop leakages [2, 25]. Selecting a configuration is one of the key steps before designing a hybrid system. This work presents various configurations of the SOFC - gas turbine hybrid system and discusses the unit of each configuration. Once the optimum configuration is selected, a complete cycle analysis is presented.

\subsection{Solid oxide fuel cell modeling}

The mathematical model of the button cell was implemented to evaluate the voltage response for given current densities, fuel and air compositions, and cell temperature. The model performs a "unit-cell" calculation at steady state, assuming fuel composition, air composition, and temperature are homogeneous over the active area. Although the form of the algorithm is based on theoretical 
treatments of the overpotential terms, several adjustable parameters are used to calibrate the model to closely match actual small-scale single-cell data that was taken over a range of temperatures and fuel compositions. The unit button cell model assumes a constant operating temperature, which is fixed experimentally using a furnace. The details of this model are presented in our previous works [22, 24, 26-27] and can be briefed that for this SOFC unit cell is a microscopic model based on the assumption that the electrodes were formed by spherical-shape particles and takes into account electronic, ionic, and gas transport together with the electrochemical reaction. It also considers the influence of the electrode structures on the electrochemical reaction at the three phase boundary (TPB).

As mentioned earlier, the single cell model is extended into a stack model before creating a SOFC hybrid system. An operating point in figure 3 that is an example for a SOFC operates at 1073 $\mathrm{K}, 97 \% \mathrm{H}_{2}$ and $3 \% \mathrm{H}_{2} \mathrm{O}$, which shows the chosen voltage curve and the corresponding current density that are used to size the stack. Based on the given specifications (bus voltage, $V_{\text {bus }}($ volt)), the number of cells required $\left(n_{\text {cells }}\right)$ can be calculated. In this work, a current density of $1 \mathrm{~A} . \mathrm{cm}^{-2}$ was chosen for the SOFC operates at an average temperature of $1073 \mathrm{~K}$ and at the difference operating conditions, so the chosen current density is changed.

The number of single cells required $\left(n_{\text {cells }}\right)$ to form the stack is computed as

$$
n_{\text {cells }}=\frac{V_{\text {bus }}}{V_{\text {cell }}}
$$

Where $V_{\text {cell }}$ (volt) is single cell voltage.

Equation (1) assumes that the cells are arranged in series. Similarly, the area of each cell $(A$, $\mathrm{cm}^{-2}$ ) within the stack can be calculated using the single cell current density $\left(i_{\text {cell }}, \mathrm{A} . \mathrm{cm}^{-2}\right)$ and the stack current as shown in equation (2) :

$$
A=\left(\frac{W_{\text {max }}}{V_{\text {bus }}}\right) / i_{\text {cell }}
$$


Other components of the hybrid system like heat exchanger, compressor, gas turbine, and combustor have been modeled using the same simulation tool. All the components have been integrated to form a cogeneration power system and thermodynamic behavior the cycle that can be being studied.

\subsection{Component models}

\subsubsection{Compressor model}

In the hybrid system, ambient air is compressed using the compressor and supplied to the SOFC. Model of the compressor is based on the perfect gas equations and polytropic transformations. Following equations have been used in compressor model

The exhaust temperature:

$$
T_{e}=T_{i}\left(\frac{p_{e}}{p_{i}}\right)^{\left(\gamma_{a}-1\right) / \gamma_{a} \eta_{\infty o c}}
$$

Where, $\mathrm{i}$ is inlet, e is exit, $\mathrm{P}$ is pressure, $\mathrm{T}$ is temperature, $\gamma_{a}=C_{p a} / C_{v a}$ or ratio of specific heats of air and $\eta_{\infty}$ is polytropic efficiency of the compressor.

Change in isentropic enthalpy:

$$
\Delta h_{C}=C_{p a} T_{i}\left(\frac{P_{e}}{P_{i}}\right)^{R_{a} / C_{p a}}-1
$$

Efficiency of the compressor:

$$
\eta_{C}=\frac{1-\left(p_{e} / p_{i}\right)^{\left(\frac{\gamma_{a}-1}{\gamma_{a}}\right)}}{1-\left(p_{e} / p_{i}\right)^{\left(\frac{\gamma_{a}-1}{\gamma_{a} \eta_{\infty}}\right)}}
$$

Mechanical power consumed by the compressor:

$$
P_{C}=\frac{q_{\text {air }} \Delta h_{C}}{\eta_{C} \eta_{\text {trans }}}
$$


Where $q_{\text {air }}$ is the air flow rate in $\mathrm{kg} . \mathrm{s}^{-1}$ and $\eta_{\text {trans }}$ is the transmission efficiency from turbine to compressor.

\subsubsection{Turbine model}

In the hybrid system, turbine is used to drive the compressor and as a secondary electrical power device. Turbine has been modeled in the same way as the compressor following gas turbine equations for a uniform polytropic expansion.

The exhaust temperature:

$$
T_{e}=T_{i}\left(\frac{p_{e}}{p_{i}}\right)^{\left(\gamma_{g}-1\right) / \gamma_{g} \eta_{\infty} T G}
$$

Where, $\mathrm{i}$ is inlet, $\mathrm{e}$ is exit, $\mathrm{P}$ is pressure, $\mathrm{T}$ is temperature, $\gamma_{g}=c_{p g} / c_{v g}$ is ratio of specific heats of combustion gases and $\eta_{\infty T G}$ is polytropic efficiency of the turbine

Change in isentropic enthalpy:

$$
\Delta h_{T G}=C_{p g} T_{i}\left(\frac{p_{e}}{p_{i}}\right)^{R_{g} / C_{p g}}-1
$$

Gas Turbine efficiency:

$$
\eta_{T G}=\frac{1-\left(p_{e} / p_{i}\right)^{\left(\frac{\gamma_{a}-1}{\gamma_{a} \eta_{\infty} T G}\right)}}{1-\left(p_{e} / p_{i}\right)^{\left(\frac{\gamma_{g}-1}{\gamma_{g}}\right)}}
$$

Now, the mechanical power delivered by the gas turbines can be calculated as:

$$
P_{T G}=\eta_{T G} q_{T G} \Delta h_{T G}
$$

And finally, mechanical power delivered to the Generators to produce electricity:

$$
P_{M G}=P_{T G}-P_{C}
$$




\subsubsection{Heat exchanger model}

Hybrid system is using parallel flow heat exchanger model. The heat exchanger is modeled as:

$$
\begin{gathered}
\Delta T_{1}=T_{h, 1}-T_{c, 1} \\
\Delta T_{2}=T_{h, 2}-T_{c, 2}
\end{gathered}
$$

Where, $\Delta T_{1}$ and $\Delta T_{2}$ are the stream-to-stream temperature differences in the front and back section of heat exchanger:

The proportionality between total heat transfer rate $\mathrm{q}$ and the overall thermal conductance of the heat exchanger surface is:

$$
q=U A \Delta T_{l m}
$$

Where $\Delta T_{l m}$ is the log mean temperature difference (LMTD) and defined as :

$$
\Delta T_{l m}=\frac{\Delta T_{2}-\Delta T_{1}}{\ln \left(\frac{\Delta T_{2}}{\Delta T_{1}}\right)}
$$

And, $d q=-C d T$ gives the exit streams temperatures once $q$ is known, $\mathrm{U}$ is Overall heat transfer coefficient, A is Total heat transfer area.

\subsubsection{Combustor model}

The streams coming out of the fuel cell are burned with additional fuel and air in the combustor and the high temperature exhaust is sent to turbine. Following equation models the flow in the combustor.

Enthalpy of Fuel Cell Streams + Enthalpy of additional fuel = Net Enthalpy of the mixture

$$
d H=C_{p}(T) d T
$$

Using the above equation and known mixture enthalpy, 


$$
\Delta h_{C}=C_{p a} T_{i}\left(\frac{p_{e}}{p_{i}}\right)^{R / C_{p a}}-1
$$

Exhaust temperature is calculated. Model assumes the complete combustion and there are no $\mathrm{NO}_{\mathrm{x}}$ formed during the combustion.

\section{Hybrid solid oxide fuel cell and gas turbine system configurations and cycle analysis}

Deciding upon the optimum configuration is one of the key steps in modeling a gas turbine hybrid system. In this work, a few configurations of the hybrid system are simulated and their performances are analyzed. Based upon the comparative study, the better configuration is chosen and discussed in detail. The basic parameters that are focused, in choosing the optimum configuration, are the cycle efficiency and the fuel cell power.

The modeling assumptions, operating conditions and cycle configurations are shown below.

\subsection{Modeling assumptions and operating conditions}

Due to the solid oxide fuel cell and gas turbine hybrid system usually use as an auxiliary aerospace power. The models in this work aim for the aircraft applications. Sea level full power is taken as the design condition of the system. For aircraft applications, this choice is based upon the fact that the exhaust pressure at sea level is higher than the one at cruise altitude. In this way, the power extracted from the turbine will be less and to meet the power requirements the stack power needs to be higher. Higher stack power means higher heat and higher external cooling and thus higher air flow rate to the stack. Higher airflow rates require higher compressor power and higher turbine work. Therefore, the line of arguments suggests that sea level full power should be the design point. The fuel cell power is maximized at the design point. This design point selection and the operating conditions for the cycle components and reasoning are taken from [28].

- The operating conditions for the cycle components and the design point are: 
Turbine Pressure ratio: 2.37

Fuel composition: $97 \% \mathrm{H}_{2}+3 \% \mathrm{H}_{2} \mathrm{O}$ per mol

Air composition: $21 \% \mathrm{O}_{2}+79 \% \mathrm{~N}_{2}$ per mol

Design Temperature: $25^{\circ} \mathrm{C}$

Design Pressure: $1 \mathrm{~atm}$

- For comparison the models assume that the cycles are running at design point until the optimum configuration is chosen.

- Pressures losses in the fuel cell, combustor, and piping are negligible.

- The combustor of the model is based on simple combustion reactions and does not include the actual chemistry of the reaction and the complete system is adiabatic i.e. no wall heat losses.

- Hydrogen is used as a fuel and hence internal reforming and desulphurization have not been incorporated.

\subsection{The configurations}

Deciding upon the better configuration is one of the key steps in modeling a gas turbine hybrid system. In this work, a few configurations of the hybrid system are simulated and their performances are analyzed. Based upon the comparative study, the better configuration is chosen and discussed in detail. The basic parameters that are focused at, in choosing the better configuration, are the cycle efficiency and the fuel cell power. Initial values like SOFC power required, heat exchanger, turbine/compressor specifications etc. are temporary values and have been assumed to get an idea how system performance depends upon the operating parameters. These values can be changed depending on the system requirements. The first configuration has been chosen based upon the idea that since combustor exhaust is at high temperature, even the low mass flow rate will be enough to heat the fuel stream to a required temperature. In the second configuration that the only difference is that both (fuel 
and air) streams are heated by the turbine exhaust. Both configurations are shown below in figures 4 and 5. For both configurations the compressor, SOFC, turbine and combustor efficiencies are $68.5 \%$, $45 \%, 88.4 \%$ and $100 \%$, respectively.

From the Table 1, it can be seen that configuration 2 has lower performance and configuration 1 gives the better steady state performance. Configuration 1 gives $58 \%$ cycle efficiency. We can say that the low performance of configuration 2 can be attributed to the low operating temperature of the fuel cell stack, as the SOFC performance is directly proportional to the operating temperature. As we instead from configuration 2 by 1 , the operating temperature improves and hence the performance of the fuel cells.

The configuration 1 is chosen as the better configuration out of the configurations studied. Due to the compressed high temperature exhaust from the combustor is expanded in the turbine and low mass flow rate stream is used to heat the fuel before enter to the SOFC, so it is the reason that the SOFC operating temperature is higher than another configuration. The enthalpy of the exhaust leaving the turbine is high enough to give the required preheating to the air stream in the air heat exchanger. The exhaust from the air heat exchanger is released to the ambient. The cycle efficiency obtained in this case is $58 \%$ and the power of the fuel cell is around $77.54 \%$ of the total power. The turbine inlet temperature is also within the limits (lower than $1477^{\circ} \mathrm{C}$ or $1750 \mathrm{~K}$ ).

The data for configuration 1 gives an impression that if heat exchanger's overall heat transfer is changed. Considering this, configuration 1 is further analyzed and Table 2 shows the results in a table form. As it can be seen the efficiency of configuration 1 is not changing as the overall heat transfer coefficient is changed (the air mass flow rate is constant and equal to $400 \mathrm{~g} / \mathrm{s}$ ). The reason for this behavior, is that even at the minimum heat transfer coefficient, the heat exchanger is operating at maximum effectiveness and is allowing the maximum heat transfer. It is very interesting to study 
about the performance and characteristic behavior of the configuration 1 when both of the overall heat transfer coefficient and air mass flow rate are changed that is shown in next section.

\subsection{Sensitivity study of configuration 1}

Table 3 shows the data for configuration 1 at different air flow rates for varying overall heat transfer coefficients or UA $\left(\mathrm{W} . \mathrm{K}^{-1}\right)$. 'Forbidden' means that a particular condition is not permissible as the maximum allowable turbine inlet temperature. As we move from low overall heat transfer coefficients to high overall heat transfer coefficients, the 'forbidden' operating condition shifts to the higher air flow rates. An overall heat transfer coefficient or UA, is used in configuration 1 with data from $[28,29]$.

Figures 6 to 10 show these variations. Figure 6 is the sensitivity study of the different air flow rates on the variation of the stack temperature for varying of the overall heat transfer coefficient or UA. The stack temperature plot shows that at all of UA, the stack temperature becomes more sensitive to the change of air flow rate. Figure 7 is the sensitivity study of the different air flow rates on the variation of the cycle efficiency for varying of overall heat transfer coefficient or UA. The efficiency plot shows that at $\mathrm{UA}=7000 \mathrm{~W} \cdot \mathrm{K}^{-1}$, the cycle efficiency becomes insensitive to the change of air flow rate. When the air flow changes from 0.65 to 0.75 , efficiency changes from $65 \%$ to $60 \%$ but the stack temperature and turbine inlet temperature improve significantly. Figure 8 is the sensitivity study of the different air flow rates on the variation of the turbine inlet temperature for varying of overall heat transfer coefficient or UA. The turbine inlet temperature plot shows that at all of UA, the turbine inlet temperature becomes more sensitive to the change of air flow rate. Figure 9 is the sensitivity study of the different air flow rates on the variation of the exhaust temperature for varying of overall heat transfer coefficient or UA. The exhaust temperature plot shows that at all of UA, when the air flow changes from 0.65 to 0.75 that the exhaust temperature is in the less different. 
Figure 10 is the sensitivity study of the different air flow rates on the variation of the heat exchanger effectiveness or it is defined as the ratio of the actual amount of heat transferred to the maximum possible amount of heat that could be transferred with an infinite area for varying of overall heat transfer coefficient or UA. The heat exchanger effectiveness plot shows that at all of UA, the heat exchanger effectiveness becomes more sensitive to the change of air flow rate.

\section{Improved configuration 1}

\subsection{Improved configuration 1 design performance}

From the previous analysis we have fixed the configuration and the components specifications. So far configuration 1 is based on the simplified compressor and turbine models. The models are now modified to include turbine and compressor maps. The improved model of configuration 1 uses performance maps for a real compressor (DLR radial) and turbine (NASA-CR-174646). A compressor is generally designed for a basic set of delivery pressure, temperature, isentropic efficiency, and air flow rate. These parameters depend upon the shaft speed, inlet temperature, pressure, and thermodynamic properties of the gas. When the compressor operates under this condition, it is often referred as design point operation. Operation under any other condition is referred to as off-design operation. Experimental results from off-design operation are often summarized in performance maps, in which the number of free variables is reduced by use of non-dimensional parameters for better readability. Dimensional analysis shows that constant corrected speed lines (Equation 18) can be plotted in two charts with corrected flow rate (Equation 20) on the x-axis, and with isentropic efficiency $(\eta)$ or pressure ratio ( $\pi$, Equation 19) on the y-axis. In Equations 18 to 20 the subscripts 01 and 02 relate to the stagnation values at the entry and exit, respectively. $\mathrm{T}$ and $\mathrm{P}$ are the reference temperature and pressure. The performance map for the modeled radial compressor, based on [29], is shown in Figure 11. 


$$
\begin{gathered}
N_{\text {corr }}=\frac{N}{\sqrt{T_{01} / T_{a}}} \\
\pi=\frac{P_{02}}{P_{01}} \\
m_{\text {corr }}=\frac{m \sqrt{T_{01} / T_{a}}}{P_{01} / P_{a}}
\end{gathered}
$$

The line in the bottom map of Figure 11, connects all the constant rpm lines and is called the surge line. Operation above this line may cause the compressor to surge and performance will breakdown, when increase the air flow, the pressure at the start of the compressor will thus decrease. However, the pressure upstream in the compressor hasn't noticed the change yet. There is thus a higher pressure upstream than downstream. This can cause flow reversal in the compressor. Flow reversal itself is already bad. However, it doesn't stop here. The flow reversal causes the pressure upstream in the compressor to drop. This causes the compressor to start running again. The pressure upstream again increases. Also, the air flow increases. But this again causes the pressure downstream to increase. Flow reversal thus again occurs. A rather unwanted cycle has thus been initiated. This cyclic phenomenon is called surge. It causes the whole compressor to start vibrating at a high frequency, violent oscillations in pressure, propagation of pressure waves, and failure of the entire compression system. However, surge is different from stall, in that it affects the entire compressor. The stall is no flow due to the angle of incidence is too far off, then the flow can't follow the curvature of the rotor blades or sometime stall limited flow but surge is the reversal of flow in the compressor. The occurrences of stall can often lead to surge.

Unlike a compressor (or fan), surge (or stall) does not occur in a turbine. This is because the flow through the unit is all 'downhill', from high to low pressure. Consequently there is no surge line marked on a turbine map. Because of increasing the pressure ratio usually leads to an increase in mass flow. However, after a certain point, the mass flow will not increase further. This is called choked 
flow. It occurs, when the flow reaches supersonic velocities. Choked flow can also occur at the compressor. A turbine is generally choked while operating near the design point. The exit stream properties can be calculated from the choked flow condition using equation 21.

$$
\frac{m}{m_{D P}}=\frac{P_{i}}{P_{e}} \sqrt{\frac{1-\left(\frac{P_{e}}{P_{i}}\right)^{2}}{1-\left(\frac{P_{e}}{P_{i}}\right)^{2} D P}}
$$

Where the subscript 'DP', 'i', 'e' represent the design point, inlet and outlet of the turbine, respectively. Figure 12 shows the generic performance map of the radial turbine used in the present modeling. The experimental data for the radial turbine is taken from the Kurzke's "Map Collection 2" referred to as NASA-CR-174646 [29]. As it can be seen from the generic maps, the turbine has a very large operation range in the choked condition. However, if the pressure ratio is low, the chocked assumption is no longer valid, and performance maps are required.

\subsection{Performance analysis}

The presented work is an attempt to model a solid oxide fuel cell and gas turbine hybrid system for auxiliary aerospace power is analyzed using a system-level model. The system is designed to produce $440 \mathrm{~kW}$ of net electrical power, sized for a typical long-range 300-passenger civil airplane especially at sea level conditions. The system is compared to an earlier version that was designed by Freeh et al. [28] for sea level operation of the aircraft to also produce $440 \mathrm{~kW}$ of net electrical power. The earlier version of a hybrid system for aircraft application [28] is shown in figure 13. Figure 13 is a bottoming cycle in which the remaining fuel from the exhaust of the SOFC system is burned in a small combustor to produce additional heat energy for two heat exchangers and the turbine. The turbine drives a compressor that compresses the air for both the fuel cell and reformer. Any residual turbine power is converted to electrical power using a generator. The reformer is assumed to use 
partial-oxidation chemistry though some water is added to prevent coking. Both the compressor and turbine are assumed to be single-stage radial designs. The fuel and water pumps are simple low pressure, low flow rate, liquid pumps whose required work is negligible compared to that of the gas compressor. The mass and volume of each of the pumps are considered in the system mass estimate, however. The air heat exchanger is a compact gas-gas cross flow heat exchanger and the steam generator is a multi-pass gas-liquid design. No recycling of either the anode or cathode streams is considered to simplify the model and it operates at steady state condition similar to our present work. The net thermal efficiencies of an earlier version of a hybrid system [28] with respect to the fuel LHV are calculated to be $42.4 \%$ at sea level full power.

To calculate the design performance of the present model configuration, a steady state model of the hybrid SOFC-GT is developed. One more difference between base configuration 1 and its improved version is that in the latter configuration, the turbine is split into a driving and a power turbine. The reason being that the compressor and the driving turbine need to be matched. One important point to be noted is that the analysis henceforth will use some adjustable parameters (compressor air flow rate, pressure ratio) in order to simulate the same conditions as the earlier version for auxiliary aerospace power operate at sea level conditions [28].

The parameters used are:

Compressor: DLR radial

Inlet temperature: $298 \mathrm{~K}$

Inlet pressure: 14.7 psia

Design air flow rate: adjustable

Design pressure ratio: 2.88

Air heat exchanger:

Counter flow with an overall heat transfer coefficient (UA): 7000 W.K ${ }^{-1}$ 
Fuel heat exchanger:

Counter flow with an overall heat transfer coefficient (UA): $360 \mathrm{~W} . \mathrm{K}^{-1}$

Power Turbine: NASA-CR-174646

Design mass flow rate: adjustable

Design pressure ratio: 2.37

Table 4 shows the results of improved configuration 1. The parameters shown in italics are parameters at the same value as the earlier version of a hybrid system for aircraft application model in order to compare the performance with an earlier version at sea level condition [28]. The results show that the model is giving better sea level performance than the earlier version [28]. The efficiency observed for the model is $45.1 \%$ and the efficiency for the earlier model [28] is $42 \%$. The SOFC power is $71.1 \%$ of the total power while this percentage is $95.75 \%$ in the earlier model due to the different in the schematic of the components between the two models. The configuration 1 of the present model is the hybrid SOFC-GT system as shown in figure 4 that the power turbine is gas turbine. The configuration of the earlier model is the hybrid SOFC - steam turbine model as shown in figure 13 that the power turbine is the steam turbine, the major steam from the steam generator is fed to fuel reformer and some steam is fed to the steam turbine.

\section{Conclusion}

In this work a hybrid solid oxide fuel cell and gas turbine power system models are developed and analyzed by evaluating the sea level full power operating points for a 300 passenger commercial aircraft electrical power unit. Each component within the system is sized to meet the $440 \mathrm{~kW}$ input electrical load at sea level full power. Two types of models have been developed for which the individual components of the system (compressor, turbine, heat exchanger and combustor) are modeled using simple thermodynamic relations. Simple models are used in the preliminary step of the 
study and a more realistic one based on the performance maps is developed. Some important observations are made during the configuration study. They are built by means of a sensitivity study of the whole cycle for the selected configuration. The fuel cell performance is found to be a strong function of operating temperature (which depends upon the preheating of the input streams) and hence when the heat exchanger properties are varied with the air mass flow rate, the cycle performance shifts towards favorable conditions. The parameters that limit the cycle performance are the SOFC temperature, the turbine inlet temperature, and the exhaust temperature. Though at high SOFC temperatures, the cycle efficiency is high, the cycle operation under these conditions is not feasible after a certain point. The important fact found was that the selected configuration (or the configuration 1), at sea level conditions, a hybrid solid oxide fuel cell and gas turbine power system can achieve cycle system efficiency better than the earlier model from an available literature. At the present, this model is not included the dynamic analysis but once the current design is more completed then the dynamic analysis of each of the components and the cycle as a whole will be carried out and to extend the code developed previously for possible part-load simulation in the near future. However, the model presented in this work gives a starting point of that developmental process and leaves a lot of scope for future work in this direction.

\section{References}

[1] Singhal SC, Kendall K. High temperature solid oxide fuel cells: fundamentals design and applications. Oxford: Elsevier; 2003.

[2] Larminie J, Dicks A. Fuel cell systems explained. Chichester: John Wiley and Sons; 2003.

[3] Massardo AF, Lubelli F. Internal reforming solid oxide fuel cell - gas turbine combined cycles (IRSOFC-GT): part a - cell model and cycle thermodynamic analysis. ASME J Eng Gas Turb Power 2000; 122: 27-35. 
[4] Hirschenhofer JH, Stauler DB, Engleman RR, Klett MG. Fuel cell handbook. 4th ed.: Parsons corporation reading P.A. for U.S. department of energy; 1998.

[5] Chan SH, Ho HK, Tian Y. Modeling of simple hybrid solid oxide fuel cell and gas turbine power plant. J Power Source 2002; 111: 320-328.

[6] Winkler W, Lorenz $\mathrm{H}$. The design of stationary and mobile solid oxide fuel cell-gas turbine systems. J Power Sources 2002; 105: 222-227.

[7] Calise F, d'Accadia MD, Palombo A, Vanoli L. Simulation and exergy analysis of a hybrid solid oxide fuel cell (SOFC) - gas turbine system. Energy 2006; 31: 3278-3299.

[8] Calise F, d'Accadia MD, Vanoli L, von Spakovsky MR. Full load synthesis/designing optimization of a hybrid SOFC-GT power plant. Energy 2007; 32: 446-458.

[9] Haseli Y, Dincer I, Naterer GF. Thermodynamic modeling of a gas turbine cycle combined with a solid oxide fuel cell. Int J Hydrogen Energy 2008; 33: 5811-5822.

[10] Burbank Jr W, Witmera D, Holcomb F. Model of a novel pressurized solid oxide fuel cell gas turbine hybrid engine. J Power Sources 2009; 193: 656-664.

[11] Bao C, Shi YX, Li C, Cai NS, Su Q. Multi-level simulation platform of SOFC-GT hybrid generation system. Int J Hydrogen Energy 2010; 35: 2894-2899.

[12] Winkler W, Hagen L. Layout of SOFC-GT cycles with electric efficiencies over $80 \%$ : Proc 4th European Fuel Cell Forum. Lucerne Switzerland 2000: 413-420.

[13] Rao AD, Samuelsen GS. A thermodynamic analysis of tubular SOFC based hybrid systems: Proc ASME Turbo Exposition. New Orleans Louisiana U.S.A. 2001: GT-0522.

[14] Campanari S. Full load and part-load performance prediction for integrated SOFC and microturbine systems. ASME J Eng Gas Turb Power 2000; 122: 239-246. 
[15] Costamagna P, Magistri L, Massardo AF. Design and part-load performance of a hybrid system based on a solid oxide fuel cell reactor and a micro gas turbine. J Power Sources 2001; 96: 352-368.

[16] Chan SH, Ho HK, Tian Y. Modeling of a simple hybrid solid oxide fuel cell - gas turbine power plant. J Power Sources 2002; 109: 111-120.

[17] Umberto D, Gheorghe L, Dario Z, Cristian L. A matlab - simulink analysis of hybrid SOFC dynamic behavior: Proc FUELCELL2005 3rd international conference on fuel cell science engineering and technology. Michigan U.S.A. 2005: 74056-1-7.

[18] Magistri L, Bozzo R, Costamagna P, Massardo AF. Simplified versus detailed SOFC reactor models and influence on the simulation of the design point performance of hybrid systems : Proc ASME Turbo Exposition. Amsterdam The Netherlands. 2002: GT-30653.

[19] Palsson J, Selimovic A, Sjunnesson L. Combined solid oxide fuel cell and gas turbine systems for efficient power and heat generation. J Power Sources 2000; 86: 442-448.

[20] Hussain MM, Li X, Dincer I. Mathematical modeling of planar solid oxide fuel cells. J Power Sources 2006; 161: 1012 -1022.

[21] Meng N, Michael KHL, Dennis YCL. Parametric study of solid oxide fuel cell performance. Energy Convers Manage 2007; 48: 1525-1535.

[22] Chinda P, Wechsatol W, Chanchaona S, Brault P. Microscale modeling of an anodesupported planar solid oxide fuel cell. Fuel Cells 2011; 11(2): 184-199.

[23] Chinda P, Chanchaona S, Brault P, Wechsatol W. A planar anode-supported solid oxide fuel cell model with internal reforming of natural gas. Eur Phys J Appl. Phys 2011; 54(2): 23405 $-1-15$.

[24] Chinda P, Chanchaona S, Brault P, Wechsatol W. A solid oxide fuel cell micro-scale modeling with spherical particle shaped electrodes. Eur Phys J Appl. Phys 2011; 54(2): 
23411-1-16.

[25] Thorud B. Dynamic modeling and characterization of a solid oxide fuel cell integrated in a gas turbine cycle: Doctoral thesis department of energy and process engineering faculty of engineering science and technology. Norwegian University of Science and Technology; 2005.

[26] Chinda P, Chanchaona S, Brault P, Wechsatol W. Mathematical modeling of a solid oxide fuel cell with nearly spherical-shaped electrode particles. Journal of Sustainable Energy and Environment 2010; 1(4): 185-196.

[27] Chinda P, Wechsatol W, Ordonez JC. Micro-scale modeling of a solid oxide fuel cell packed with spherical-shaped electrode particles: Proc 3rd International Conference on Sustainable Energy and Environment (SEE 2009). Bangkok Thailand 2009: 786-791.

[28] Freeh JE, Steffen CJ, Larosiliere LM. Off - design performance analysis of a solid oxide fuel cell - gas turbine hybrid for auxiliary aerospace power: Proc FUELCELL2005 3rd international conference on fuel cell science engineering and technology. Michigan U.S.A. 2005: 74099-1-8.

[29] Kurzke J. Compressor and turbine maps for gas turbine performance computer programs component map collection 2. Dachau Germany: Joachim Kurzke; 2004.

\section{Nomenclatures}

A

$\mathrm{C}_{\mathrm{c}} \quad$ heat capacity of the cold stream $\left[\mathrm{J} \cdot \mathrm{s}^{-1} \cdot \mathrm{K}^{-1}\right]$

$\mathrm{C}_{\mathrm{h}} \quad$ heat capacity of the hot stream $\left[\mathrm{J} \cdot \mathrm{s}^{-1} \cdot \mathrm{K}^{-1}\right]$

$\mathrm{C}_{\mathrm{pa}} \quad$ specific heat at constant pressure of air $\left[\mathrm{J} \cdot \mathrm{kg}^{-1} \cdot \mathrm{K}^{-1}\right]$

$\mathrm{C}_{\mathrm{pg}}$ total heat transfer area $\left[\mathrm{m}^{-2}\right]$

specific heat at constant pressure of combustion gases $\left[\mathrm{J}_{\mathrm{kg}} \mathrm{kg}^{-1} \cdot \mathrm{K}^{-1}\right]$ 


\begin{tabular}{|c|c|}
\hline $\mathrm{C}_{\mathrm{va}}$ & specific heat at constant volume of air $\left[\mathrm{J} \mathrm{kg}^{-1} \cdot \mathrm{K}^{-1}\right]$ \\
\hline $\mathrm{C}_{\mathrm{vg}}$ & specific heat at constant volume of combustion gases $\left[\mathrm{J} \cdot \mathrm{kg}^{-1} \cdot \mathrm{K}^{-1}\right]$ \\
\hline$i_{\text {cell }}$ & single cell current density $\left[\right.$ A.cm $\left.{ }^{-2}\right]$ \\
\hline $\mathrm{n}_{\text {cells }}$ & the number of single cells required \\
\hline $\mathrm{P}$ & pressure [atm] \\
\hline $\mathrm{P}_{\mathrm{C}}$ & Mechanical power consumed by the compressor [Watt] \\
\hline $\mathrm{P}_{\mathrm{MG}}$ & mechanical power delivered to the generators [Watt] \\
\hline $\mathbf{P}_{\mathrm{TG}}$ & mechanical power delivered by the gas turbines [Watt] \\
\hline qair & air flow rate in $\left[\mathrm{kg} \cdot \mathrm{s}^{-1}\right]$ \\
\hline $\mathrm{T}$ & temperature $[\mathrm{K}]$ \\
\hline UA & the overall heat transfer coefficient $\left[\mathrm{W} . \mathrm{K}^{-1}\right]$ \\
\hline $\mathrm{V}_{\text {bus }}$ & bus voltage [Volt] \\
\hline $\mathrm{V}_{\text {cell }}$ & single cell voltage [Volt] \\
\hline$\gamma_{\mathrm{a}}$ & ratio of specific heat of air \\
\hline$\gamma_{\mathrm{g}}$ & ratio of specific heats of combustion gases \\
\hline$\eta_{C}$ & efficiency of the compressor [\%] \\
\hline$\eta_{\mathrm{TG}}$ & efficiency of the turbine $[\%]$ \\
\hline$\eta_{\text {trans }}$ & transmission efficiency from turbine to compressor [\%] \\
\hline$\eta_{\infty}$ & polytropic efficiency of the turbine [\%] \\
\hline$\eta_{\infty} \mathrm{C}$ & polytropic efficiency of the compressor [\%] \\
\hline$\Delta \mathrm{h}_{\mathrm{C}}$ & change in isentropic enthalpy of compressor $\left[\mathrm{J} \cdot \mathrm{mol}^{-1}\right]$ \\
\hline$\Delta \mathrm{h}_{\mathrm{TG}}$ & change in isentropic enthalpy of turbine $\left[\mathrm{J} \cdot \mathrm{mol}^{-1}\right]$ \\
\hline$\Delta \mathrm{T}_{1 \mathrm{~m}}$ & Log-Mean Temperature Difference (LMTD) [K] \\
\hline
\end{tabular}




\section{Subscripts}

$\begin{array}{ll}\text { DP } & \text { design point } \\ \mathrm{e} & \text { exit } \\ \mathrm{i} & \text { inlet }\end{array}$

\section{Table Captions}

Table 1 Comparative result for the two configurations

Table 2 Sensitivity of configuration 1 with respect to the air heat exchanger's overall heat transfer coefficient

Table 3 Data for configuration 1 for different heat transfer coefficients and air mass flow rates

Table 4 Design performance of the model and the earlier model [28]

\section{Figure Captions}

Figure 1 Schematic of a gas turbine engine based upon the Brayton cycle

Figure 2 Gas turbine engine as a bottoming cycle in a SOFC-gas turbine System

Figure 3 An example of a SOFC performance curve when an operating point is at $1073 \mathrm{~K}, 97 \% \mathrm{H}_{2}$ and $3 \% \mathrm{H}_{2} \mathrm{O}$

Figure 4 Schematic of the first configuration

Figure 5 Schematic of the second configuration

Figure 6 Configuration 1 sensitivity studies of different air flow rates $\left(\mathrm{kg} \cdot \mathrm{s}^{-1}\right)$ on the stack temperature $(\mathrm{K})$ for varying overall heat transfer coefficients (UA, W.K ${ }^{-1}$ )

Figure 7 Configuration 1 sensitivity studies of different air flow rates $\left(\mathrm{kg} \cdot \mathrm{s}^{-1}\right)$ on the cycle efficiency (\%) for varying overall heat transfer coefficients (UA, W.K.1 $)$

Figure 8 Configuration 1 sensitivity studies of different air flow rates $\left(\mathrm{kg} \cdot \mathrm{s}^{-1}\right)$ on the turbine inlet temperature $(\mathrm{K})$ for varying overall heat transfer coefficients $\left(\mathrm{UA}, \mathrm{W} \cdot \mathrm{K}^{-1}\right.$ )

Figure 9 Configuration 1 sensitivity study of different air flow rates $\left(\mathrm{kg} \cdot \mathrm{s}^{-1}\right)$ on the exhaust 
temperature $(\mathrm{K})$ for varying overall heat transfer coefficients (UA, W. $\mathrm{K}^{-1}$ )

Figure 10 Configuration 1 sensitivity study of different air flow rates $\left(\mathrm{kg} . \mathrm{s}^{-1}\right)$ on the heat exchanger effectiveness (\%) for varying overall heat transfer coefficients (UA, W.K ${ }^{-1}$ )

Figure 11 Performance maps of the modeled compressor, based on the DLR radial compressor map (a) The relation between the corrected mass flow rate and efficiency (b) The relation between the corrected mass flow rate and pressure ratio

Figure 12 Performance map of the modeled turbine, based on the radial turbine map NASA-CR174646 (a) The relation between the pressure ratio and efficiency (b) The relation between the pressure ratio and corrected mass flow rate

Figure 13 ASPEN model of SOFC-GT hybrid system by NASA Glenn Research Center (an earlier cycle model, [28])

\section{Tables}

Table 1

\begin{tabular}{|l|c|c|}
\hline & Configuration 1 & Configuration 2 \\
\hline Fuel flow $(\mathrm{g} / \mathrm{s})$ & 9.62 & 9.62 \\
\hline Air flow $(\mathrm{g} / \mathrm{s})$ & 400 & 400 \\
\hline SOFC Temperature $\left({ }^{\circ} \mathrm{C}\right)$ & 944 & 832 \\
\hline Turbine Inlet Temp $\left({ }^{\circ} \mathrm{C}\right)$ & 1136 & 1166 \\
\hline SOFC power $(\mathrm{kW})$ & 359 & 319 \\
\hline HPT $(\mathrm{kW})$ & 104 & 108 \\
\hline Total power $(\mathrm{kW})$ & 463 & 427 \\
\hline Cycle efficiency $(\%)$ & 58 & 53.49 \\
\hline Exhaust Temp $\left({ }^{\circ} \mathrm{C}\right)($ Air HE) & 617 & 605 \\
\hline
\end{tabular}

Table 2

\begin{tabular}{|c|c|}
\hline Overall heat transfer coefficient $\left(\mathrm{UA}, \mathrm{W} \cdot \mathrm{K}^{-1}\right.$ ) & Cycle efficiency (\%) \\
\hline 1000 & 58 \\
\hline 2000 & 58 \\
\hline 3000 & 58 \\
\hline 4000 & 58 \\
\hline 5000 & 58 \\
\hline 6000 & 58 \\
\hline 7000 & 58 \\
\hline
\end{tabular}


Table 3

\begin{tabular}{|c|c|c|c|c|c|}
\hline \multicolumn{6}{|c|}{ Heat exchanger overall heat transfer coefficient $(\mathrm{UA})=1000 \mathrm{~W} \cdot \mathrm{K}^{-1}$} \\
\hline $\begin{array}{l}\text { Air flow } \\
\left(\mathrm{kg.s}^{-1}\right)\end{array}$ & $\begin{array}{c}\text { Stack } \\
\text { temp. }(\mathrm{K})\end{array}$ & $\begin{array}{c}\text { Cycle } \\
\text { efficiency }\end{array}$ & $\begin{array}{l}\text { Turbine inlet } \\
\text { temp }(\mathbf{K})\end{array}$ & $\begin{array}{l}\text { Exhaust } \\
\text { temp (K) }\end{array}$ & $\begin{array}{l}\text { Heat exchanger } \\
\text { effectiveness \% }\end{array}$ \\
\hline 0.4 & 1177 & 57.8 & 1651 & 819.5 & 78.5 \\
\hline 0.45 & 1031 & 50 & 1489 & 759 & 75 \\
\hline 0.5 & 921 & 36.5 & 1359 & 714 & 71.6 \\
\hline 0.55 & \multirow{3}{*}{\multicolumn{5}{|c|}{ Stack temp $<600{ }^{\circ} \mathrm{C}$}} \\
\hline 0.6 & & & & & \\
\hline 0.65 & & & & & \\
\hline \multicolumn{6}{|c|}{ Heat exchanger overall heat transfer coefficient $(\mathrm{UA})=2000 \mathrm{~W} \cdot \mathrm{K}^{-1}$} \\
\hline $\begin{array}{c}\text { Air flow } \\
\left(\mathrm{kg.s}^{-1}\right)\end{array}$ & $\begin{array}{c}\text { Stack } \\
\text { temp. (K) }\end{array}$ & $\begin{array}{c}\text { Cycle } \\
\text { efficiency }\end{array}$ & $\begin{array}{c}\text { Turbine inlet } \\
\text { temp (K) }\end{array}$ & $\begin{array}{l}\text { Exhaust } \\
\text { temp (K) }\end{array}$ & $\begin{array}{l}\text { Heat exchanger } \\
\text { effectiveness } \%\end{array}$ \\
\hline 0.4 & 1550 & 60 & $\begin{array}{c}1959 \\
\text { (forbidden) }\end{array}$ & 851 & 92 \\
\hline 0.45 & 1364 & 61.2 & $\begin{array}{c}1764 \\
\text { (forbidden) }\end{array}$ & 777 & 90 \\
\hline 0.5 & 1210 & 60.7 & 1599 & 720 & 87.4 \\
\hline 0.55 & 1084 & 56.2 & 1462 & 677 & 85 \\
\hline 0.6 & 983.8 & 47 & 1348 & 643 & 82.6 \\
\hline 0.65 & 901 & 35 & 1253 & 617 & 80.5 \\
\hline 0.7 & 834 & 14 & 1173 & 598 & 78.5 \\
\hline \multicolumn{6}{|c|}{ Heat exchanger overall heat transfer coefficient (UA) $=3000$ W.K $\mathbf{K}^{-1}$} \\
\hline $\begin{array}{l}\text { Air flow } \\
\left(k_{\text {kg.s }}{ }^{-1}\right)\end{array}$ & $\begin{array}{c}\text { Stack } \\
\text { temp. (K) }\end{array}$ & $\begin{array}{c}\text { Cycle } \\
\text { efficiency }\end{array}$ & $\begin{array}{l}\text { Turbine inlet } \\
\text { temp (K) }\end{array}$ & $\begin{array}{l}\text { Exhaust } \\
\text { temp (K) }\end{array}$ & $\begin{array}{l}\text { Heat exchanger } \\
\text { effectiveness } \%\end{array}$ \\
\hline 0.4 & \multirow{3}{*}{\multicolumn{5}{|c|}{ Forbidden }} \\
\hline 0.45 & & & & & \\
\hline 0.5 & & & & & \\
\hline 0.55 & 1247 & 62.5 & 1601 & 684 & 92 \\
\hline 0.6 & 1129 & 60 & 1473 & 645.4 & 90 \\
\hline 0.65 & 1030 & 53.2 & 1365 & 615 & 88.2 \\
\hline 0.7 & 948 & 43.5 & 1272 & 591.5 & 86.5 \\
\hline \multicolumn{6}{|c|}{ Heat exchanger overall heat transfer coefficient $(\mathrm{UA})=4000 \mathrm{~W} . \mathrm{K}^{-1}$} \\
\hline $\begin{array}{c}\text { Air flow } \\
\left({\left.\mathrm{kg} . \mathrm{s}^{-1}\right)}^{-1}\right.\end{array}$ & $\begin{array}{c}\text { Stack } \\
\text { temp. (K) }\end{array}$ & $\begin{array}{c}\text { Cycle } \\
\text { efficiency }\end{array}$ & $\begin{array}{l}\text { Turbine inlet } \\
\text { temp (K) }\end{array}$ & $\begin{array}{c}\text { Exhaust } \\
\text { temp (K) }\end{array}$ & $\begin{array}{l}\text { Heat exchanger } \\
\text { effectiveness } \%\end{array}$ \\
\hline 0.4 & \multirow{4}{*}{\multicolumn{5}{|c|}{ Forbidden }} \\
\hline 0.45 & & & & & \\
\hline 0.5 & & & & & \\
\hline 0.55 & & & & & \\
\hline 0.6 & 1230 & 63.2 & 1560 & 650 & 94 \\
\hline 0.65 & 1124 & 60.5 & 1445 & 617 & 92.5 \\
\hline 0.7 & 1033 & 54.2 & 1346 & 590 & 91 \\
\hline \multicolumn{6}{|c|}{ Heat exchanger overall heat transfer coefficient (UA) $=5000$ W.K ${ }^{-1}$} \\
\hline $\begin{array}{c}\text { Air } \\
\text { flow }\left(\mathrm{kg} \cdot \mathrm{s}^{-1}\right)\end{array}$ & $\begin{array}{c}\text { Stack } \\
\text { temp. }(\mathrm{K})\end{array}$ & $\begin{array}{c}\text { Cycle } \\
\text { efficiency }\end{array}$ & $\begin{array}{l}\text { Turbine inlet } \\
\text { temp (K) }\end{array}$ & $\begin{array}{l}\text { Exhaust } \\
\text { temp (K) }\end{array}$ & $\begin{array}{l}\text { Heat exchanger } \\
\text { effectiveness } \%\end{array}$ \\
\hline
\end{tabular}




\begin{tabular}{|c|c|c|c|c|c|}
\hline 0.4 & & & & & \\
\hline 0.45 & & & & & \\
\hline 0.5 & & & & & \\
\hline 0.55 & & & & & \\
\hline 0.6 & 1297 & 64.4 & 1618 & 654.4 & 96.3 \\
\hline 0.65 & 1190 & 63.3 & 1503 & 619.5 & 95.2 \\
\hline 0.7 & 1096 & 59.8 & 1401 & 591.5 & 93.9 \\
\hline \multicolumn{6}{|c|}{ Heat exchanger overall heat transfer coefficient $(\mathrm{UA})=6000 \mathrm{~W} . \mathrm{K}^{-1}$} \\
\hline $\begin{array}{l}\text { Air flow } \\
\left(\mathrm{kg.s}^{-1}\right)\end{array}$ & $\begin{array}{c}\text { Stack } \\
\text { temp. }(K)\end{array}$ & $\begin{array}{c}\text { Cycle } \\
\text { efficiency }\end{array}$ & $\begin{array}{l}\text { Turbine inlet } \\
\text { temp (K) }\end{array}$ & $\begin{array}{l}\text { Exhaust } \\
\text { temp (K) }\end{array}$ & $\begin{array}{l}\text { Heat exchanger } \\
\text { effectiveness \% }\end{array}$ \\
\hline 0.4 & \multirow{4}{*}{\multicolumn{5}{|c|}{ Forbidden }} \\
\hline 0.45 & & & & & \\
\hline 0.5 & & & & & \\
\hline 0.55 & & & & & \\
\hline 0.6 & 1342 & 65 & 1657 & 658 & 97.6 \\
\hline 0.65 & 1237 & 64.5 & 1544 & 622 & 96.7 \\
\hline 0.7 & 1142 & 62.4 & 1441 & 593 & 95.8 \\
\hline \multicolumn{6}{|c|}{ Heat exchanger overall heat transfer coefficient $(\mathrm{UA})=7000 \mathrm{~W} . \mathrm{K}^{-1}$} \\
\hline $\begin{array}{c}\text { Air flow } \\
\left(\mathrm{kg}^{-\mathrm{S}^{-1}}\right)\end{array}$ & $\begin{array}{c}\text { Stack } \\
\text { temp. }(\mathrm{K})\end{array}$ & $\begin{array}{c}\text { Cycle } \\
\text { efficiency }\end{array}$ & $\begin{array}{c}\text { Turbine inlet } \\
\text { temp (K) }\end{array}$ & $\begin{array}{l}\text { Exhaust } \\
\text { temp (K) }\end{array}$ & $\begin{array}{l}\text { Heat exchanger } \\
\text { effectiveness \% }\end{array}$ \\
\hline 0.4 & \multirow{5}{*}{\multicolumn{5}{|c|}{ Forbidden }} \\
\hline 0.45 & & & & & \\
\hline 0.5 & & & & & \\
\hline 0.55 & & & & & \\
\hline 0.6 & & & & & \\
\hline 0.65 & 1269 & 65 & 1572 & 624 & 97.8 \\
\hline 0.7 & 1176 & 63.8 & 1471 & 594 & 97 \\
\hline 0.71 & 1159 & 63.3 & 1452 & 588 & 96.9 \\
\hline 0.75 & 1092 & 60 & 1380 & 570 & 96.2 \\
\hline
\end{tabular}

Table 4

\begin{tabular}{|l|c|c|}
\hline & \multicolumn{2}{|c|}{ Parameters used } \\
\hline & Configuration-1 & Earlier hybrid model [28] \\
\hline Stack pressure & $2.9 \mathrm{bar}$ & $2.9 \mathrm{bar}$ \\
\hline Stack temperature & $850{ }^{\circ} \mathrm{C}$ & $850{ }^{\circ} \mathrm{C}$ \\
\hline Compressor inlet pressure & $14.7 \mathrm{psia}$ & $14.7 \mathrm{psia}$ \\
\hline Compressor pressure ratio & 2.88 & 2.88 \\
\hline Compressor efficiency & $83 \%$ & $83 \%$ \\
\hline Turbine outlet pressure & $17.1 \mathrm{psia}$ & $17.1 \mathrm{psia}$ \\
\hline Turbine Pressure ratio & 2.37 & 2.37 \\
\hline Turbine efficiency & $84 \%$ & $84 \%$ \\
\hline & \multicolumn{2}{|c|}{ Performance results } \\
\hline & Configuration-1 & Earlier hybrid model [28] \\
\hline SOFC net power & $342 \mathrm{~kW}$ & $429 \mathrm{~kW}$ \\
\hline Turbine power & $139 \mathrm{~kW}$ & $19 \mathrm{~kW}$ \\
\hline
\end{tabular}




\begin{tabular}{|l|c|c|}
\hline Total power & $481 \mathrm{~kW}$ & $448 \mathrm{~kW}$ \\
\hline Cycle efficiency & $45.1 \%$ & $42 \%$ \\
\hline
\end{tabular}

\section{Figures}

Figure 1

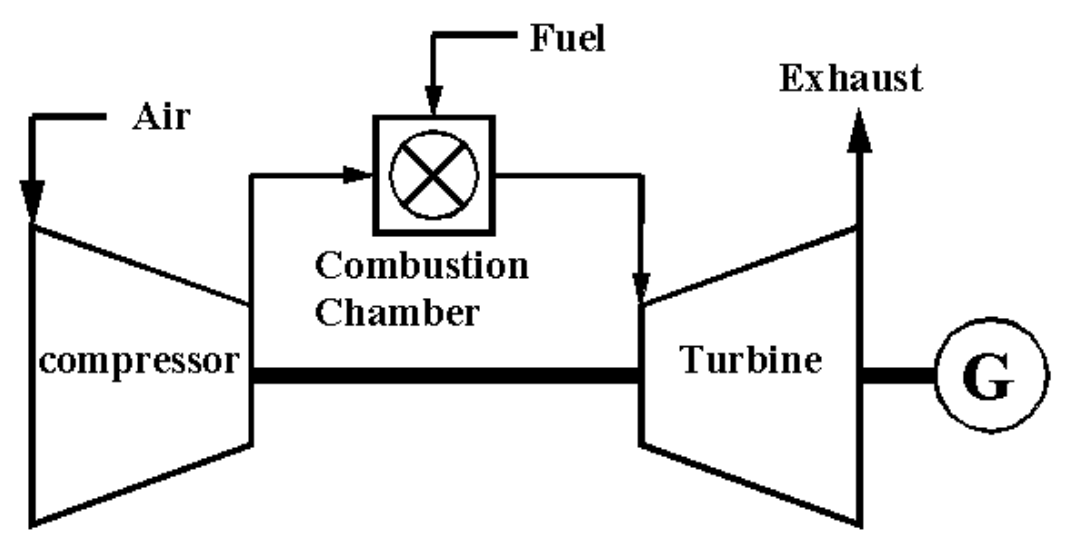

Figure 2

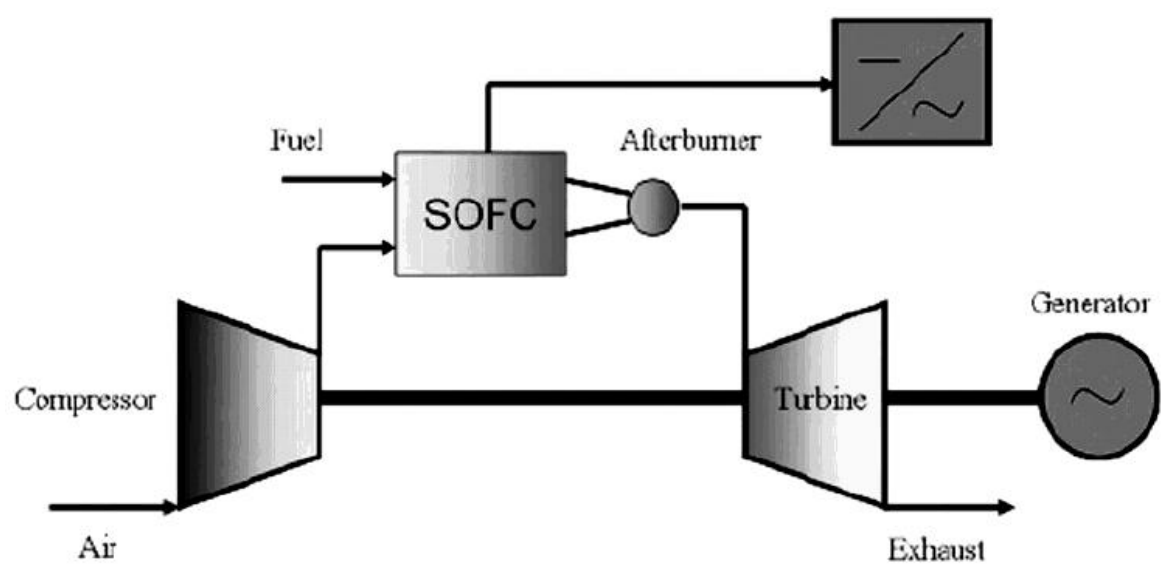

Figure 3 


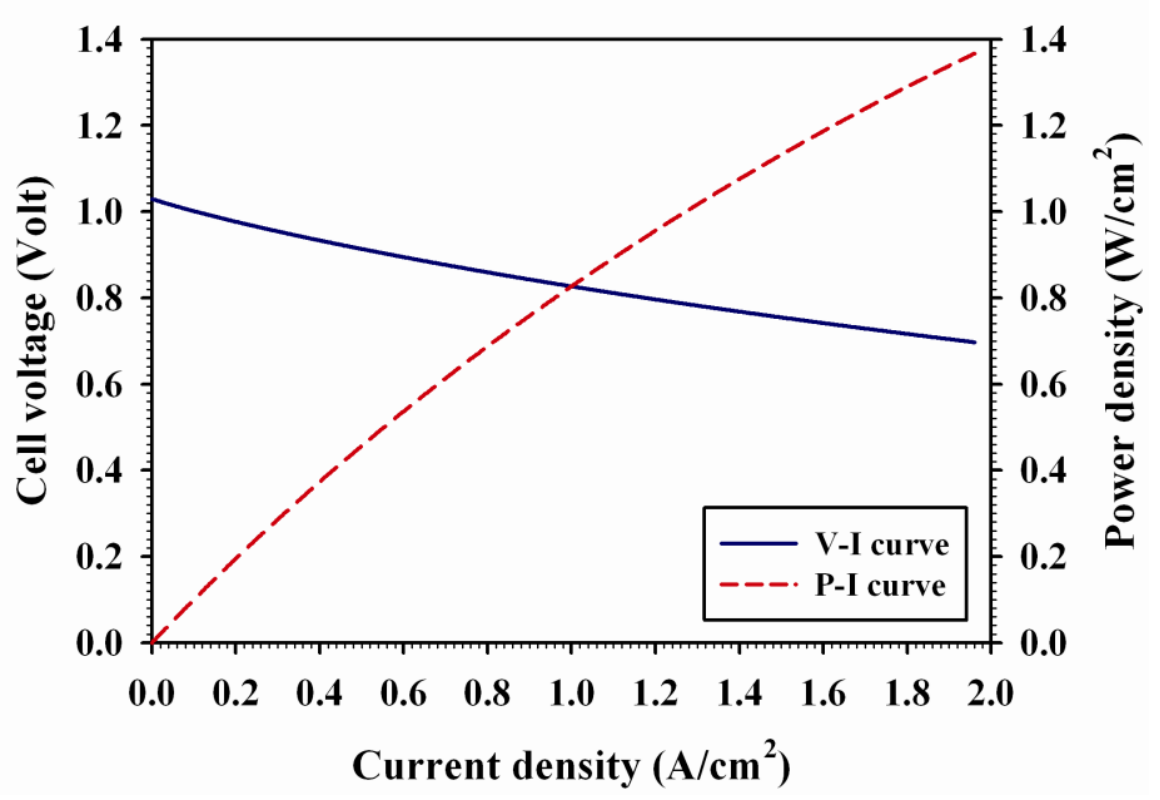

Figure 4

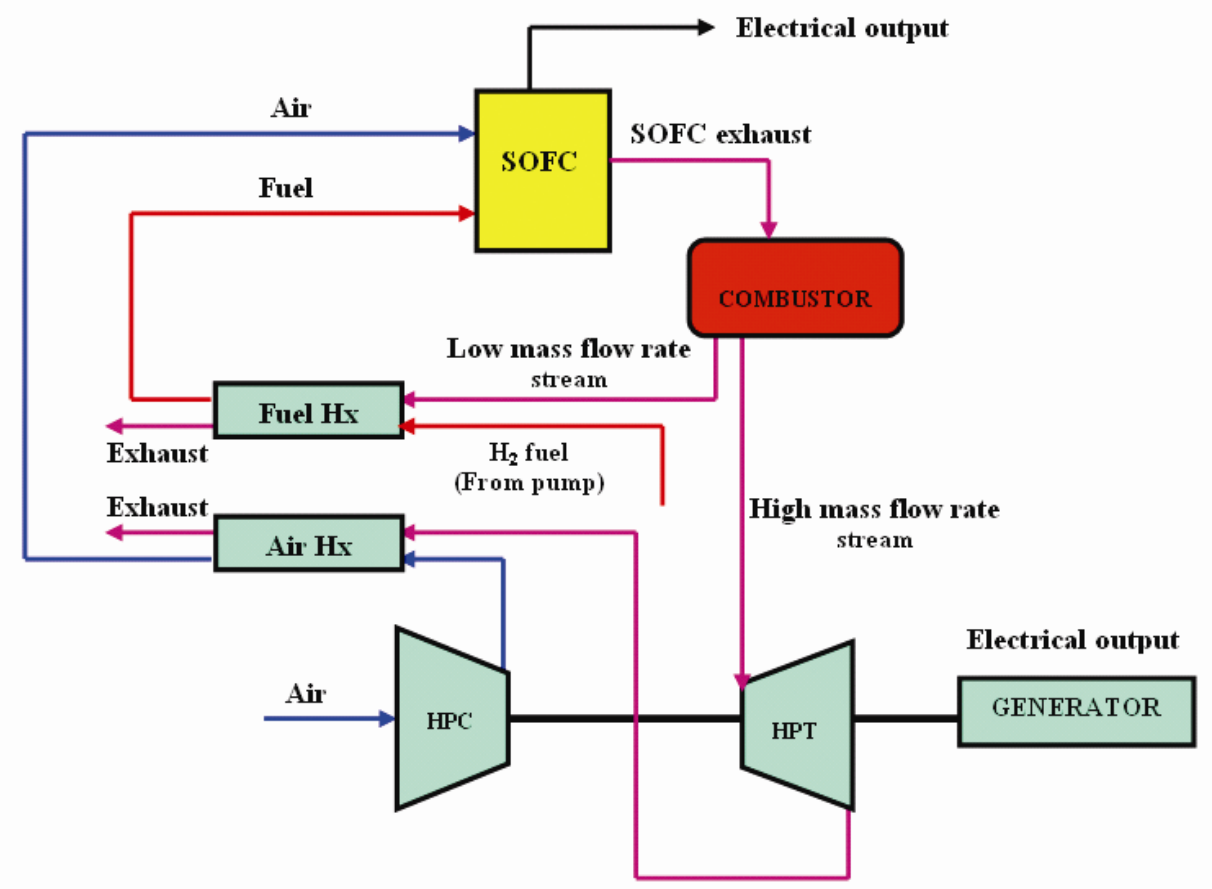

Turbine exhaust 
Figure 5

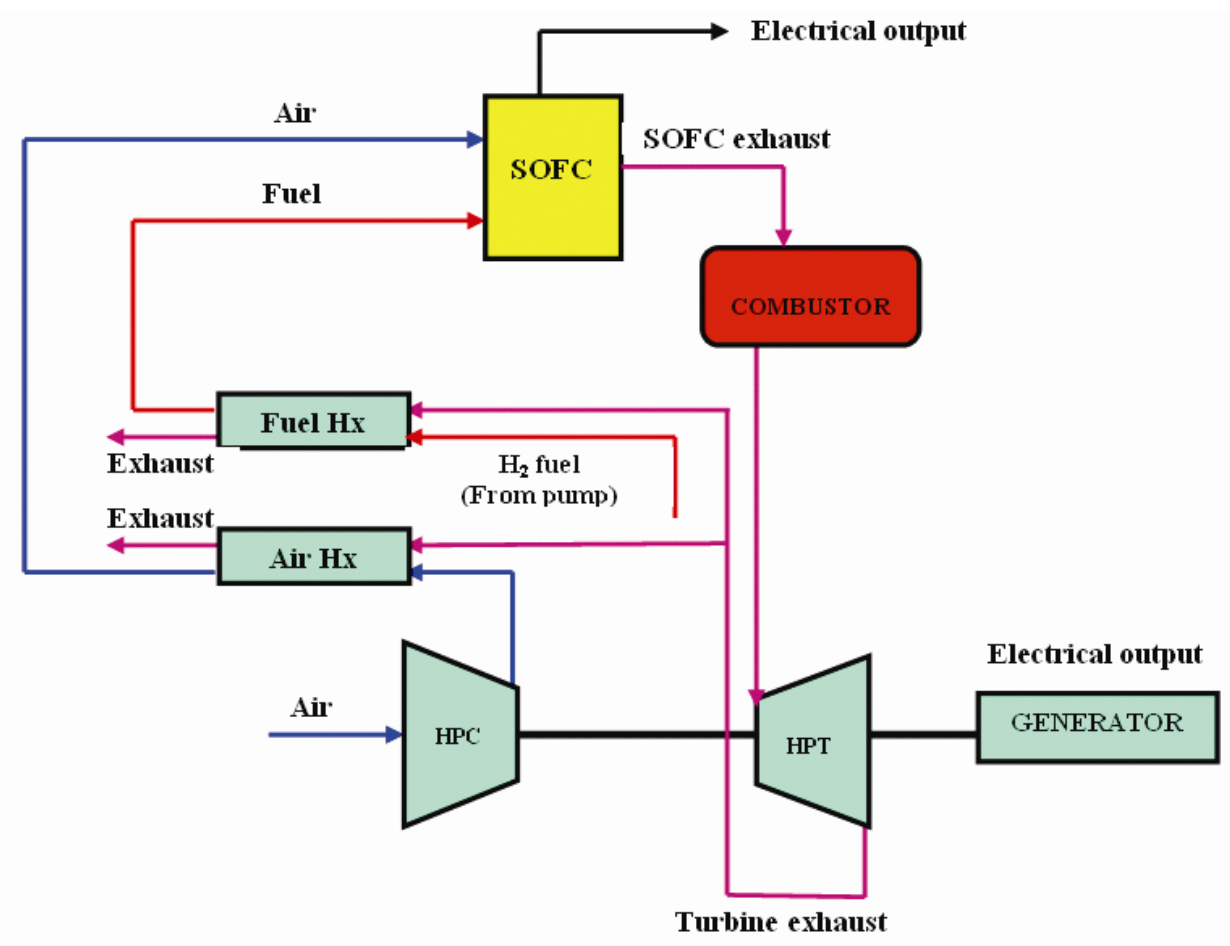

Figure 6

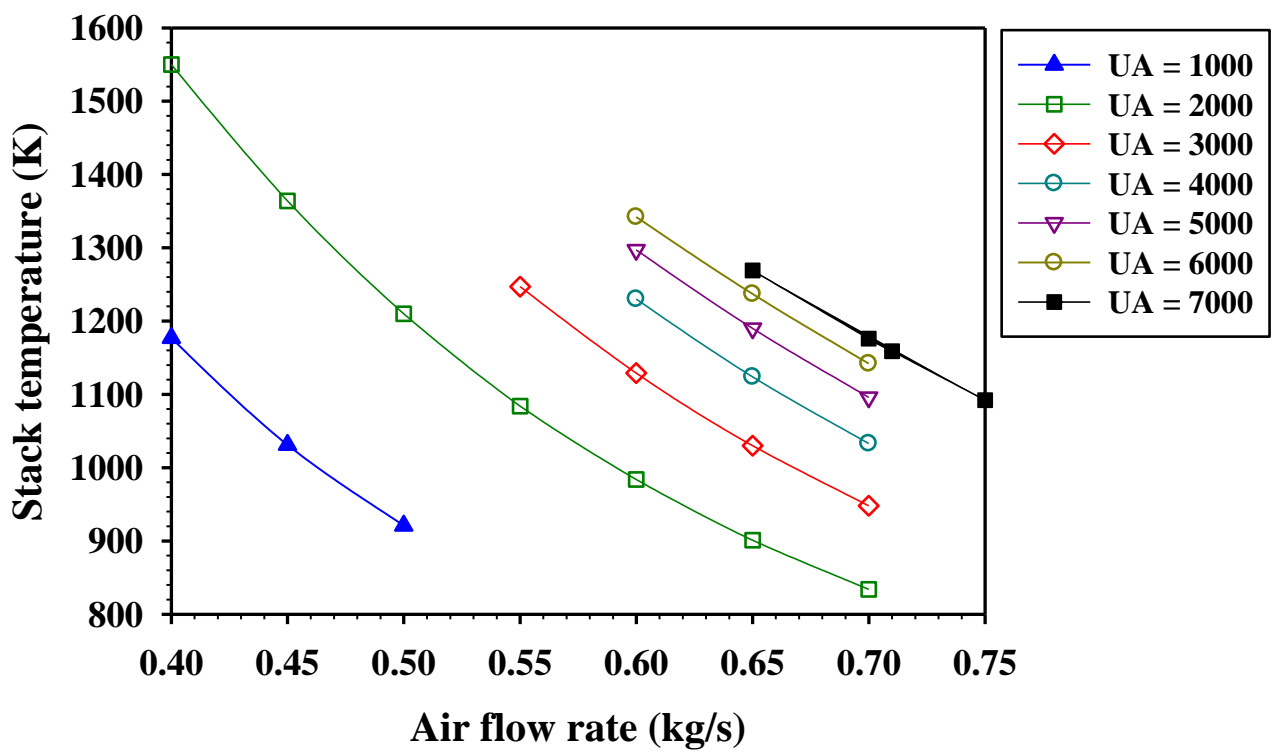


Figure 7

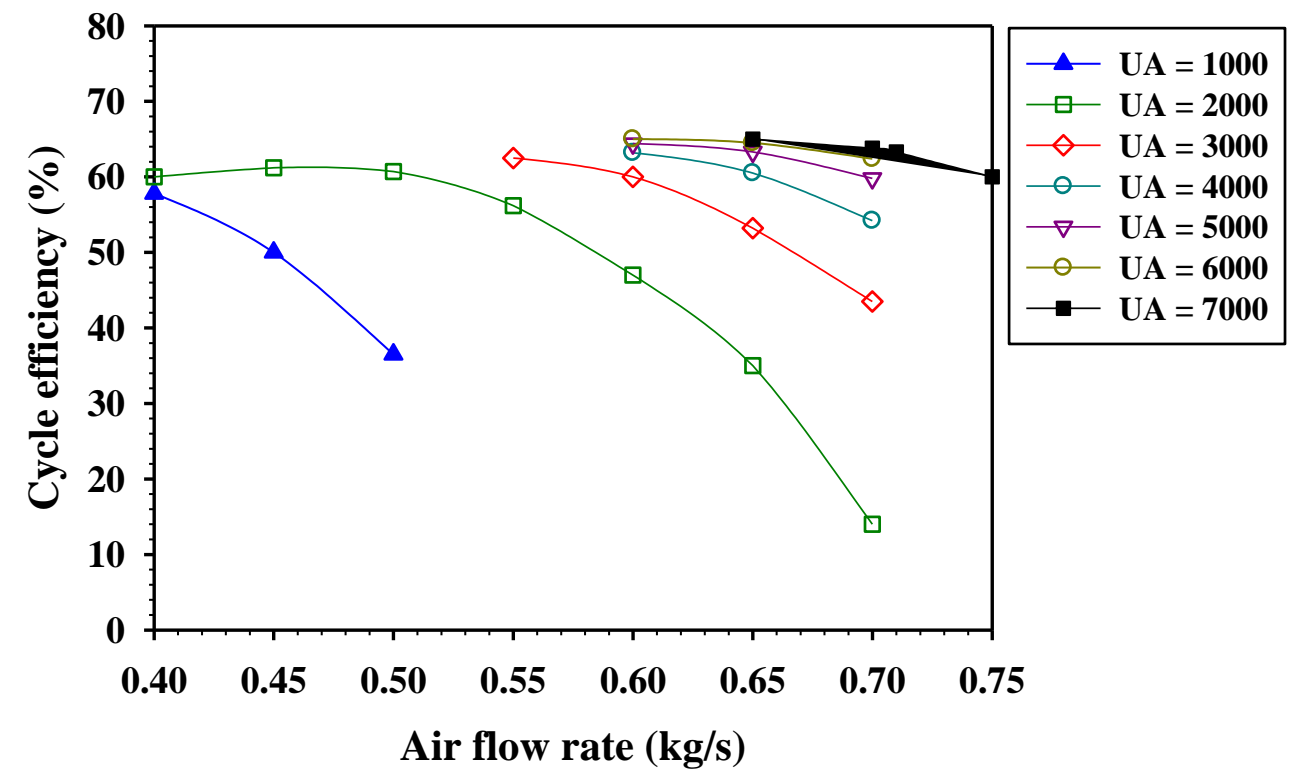

Figure 8

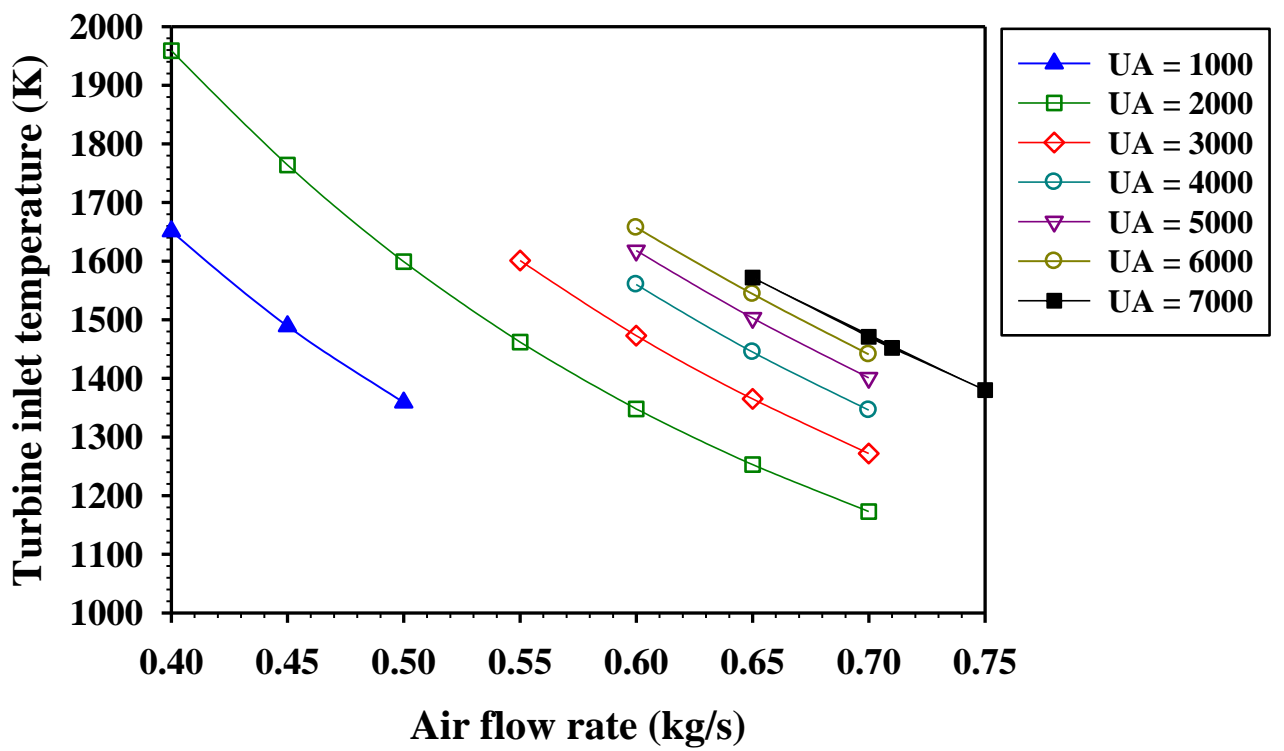


Figure 9

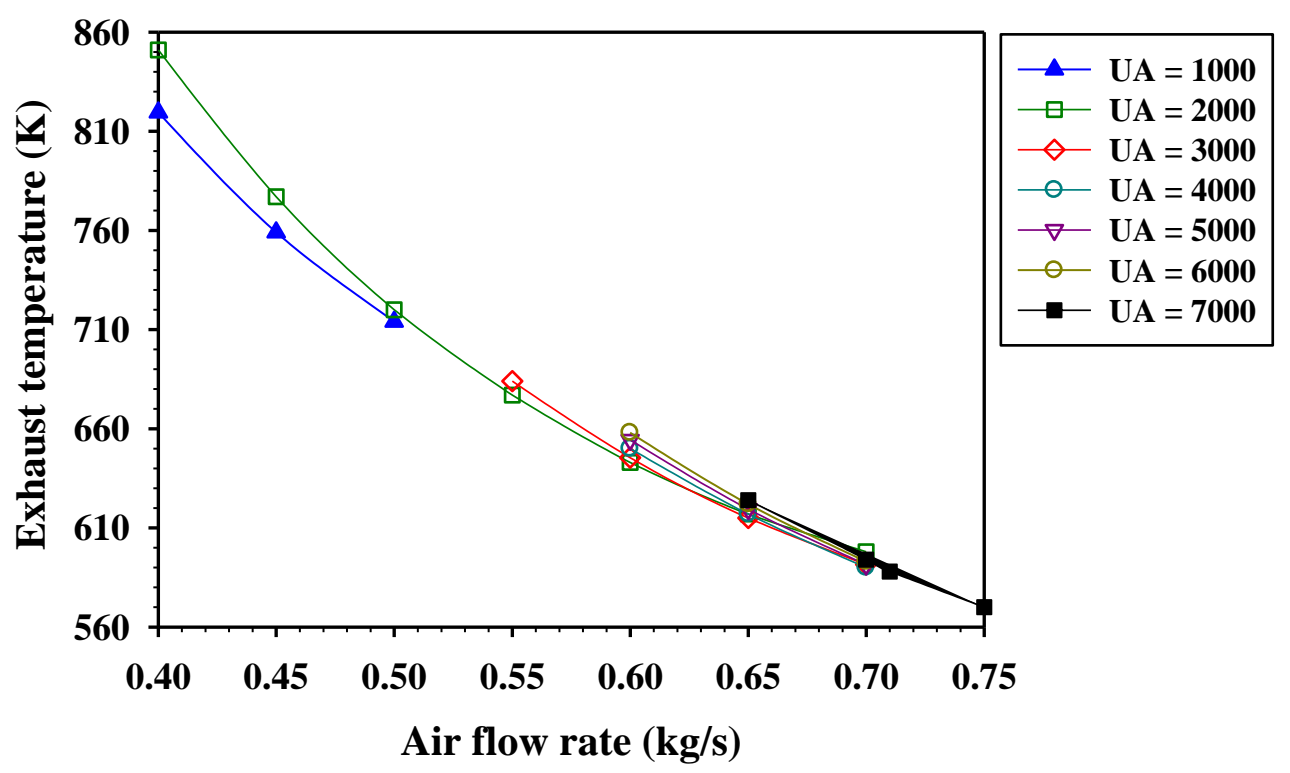

Figure 10

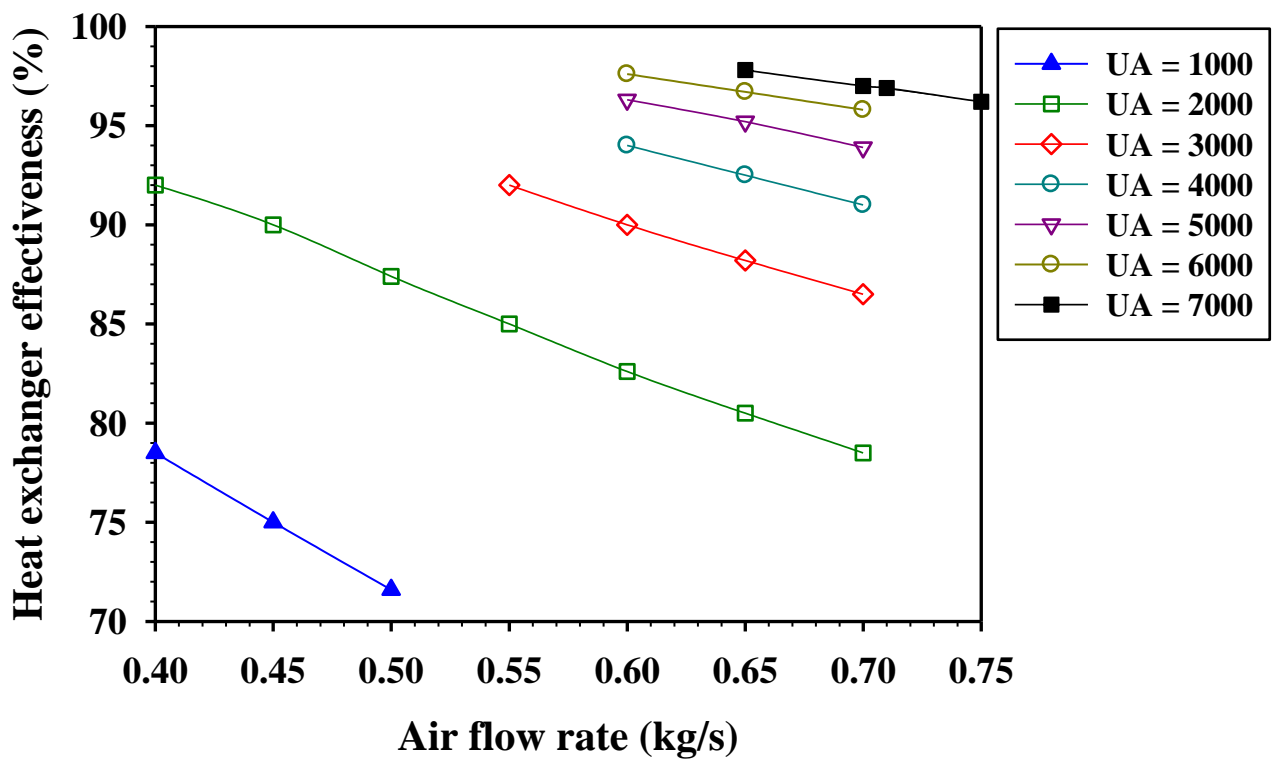


Figure 11 (a)

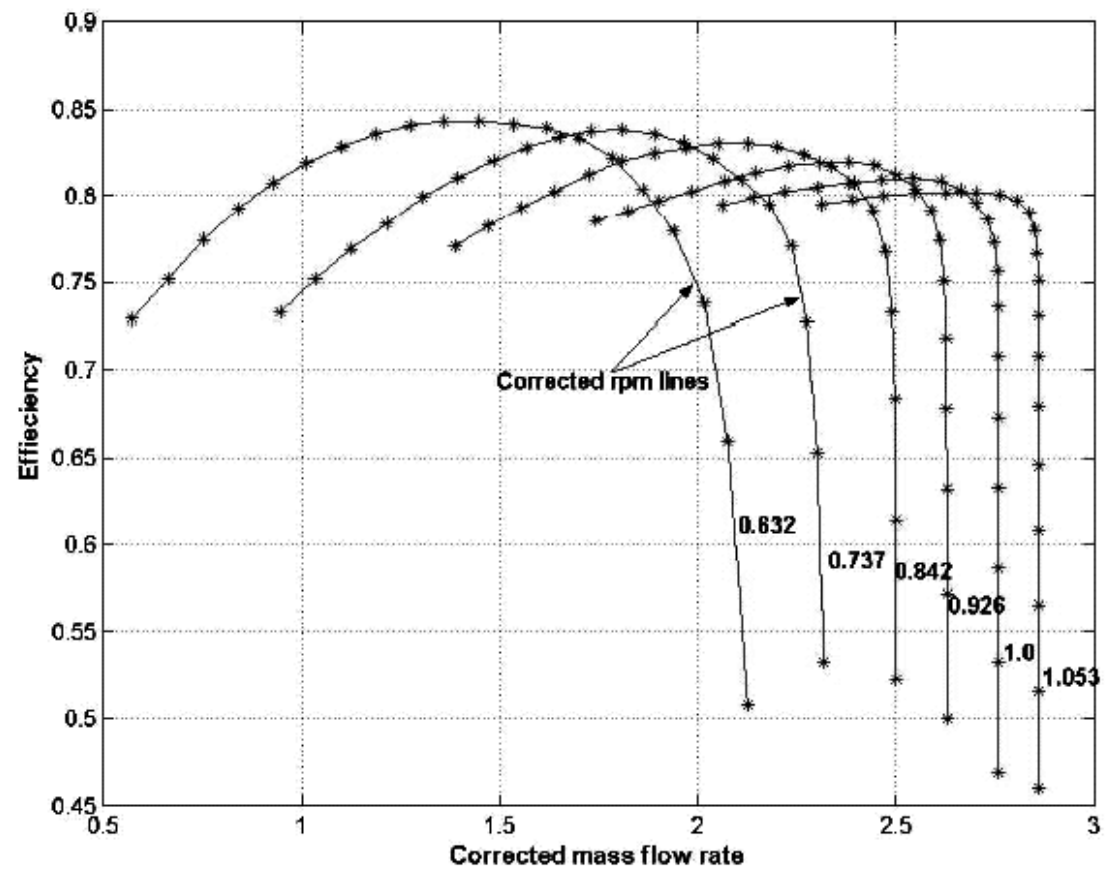

Figure 11 (b)

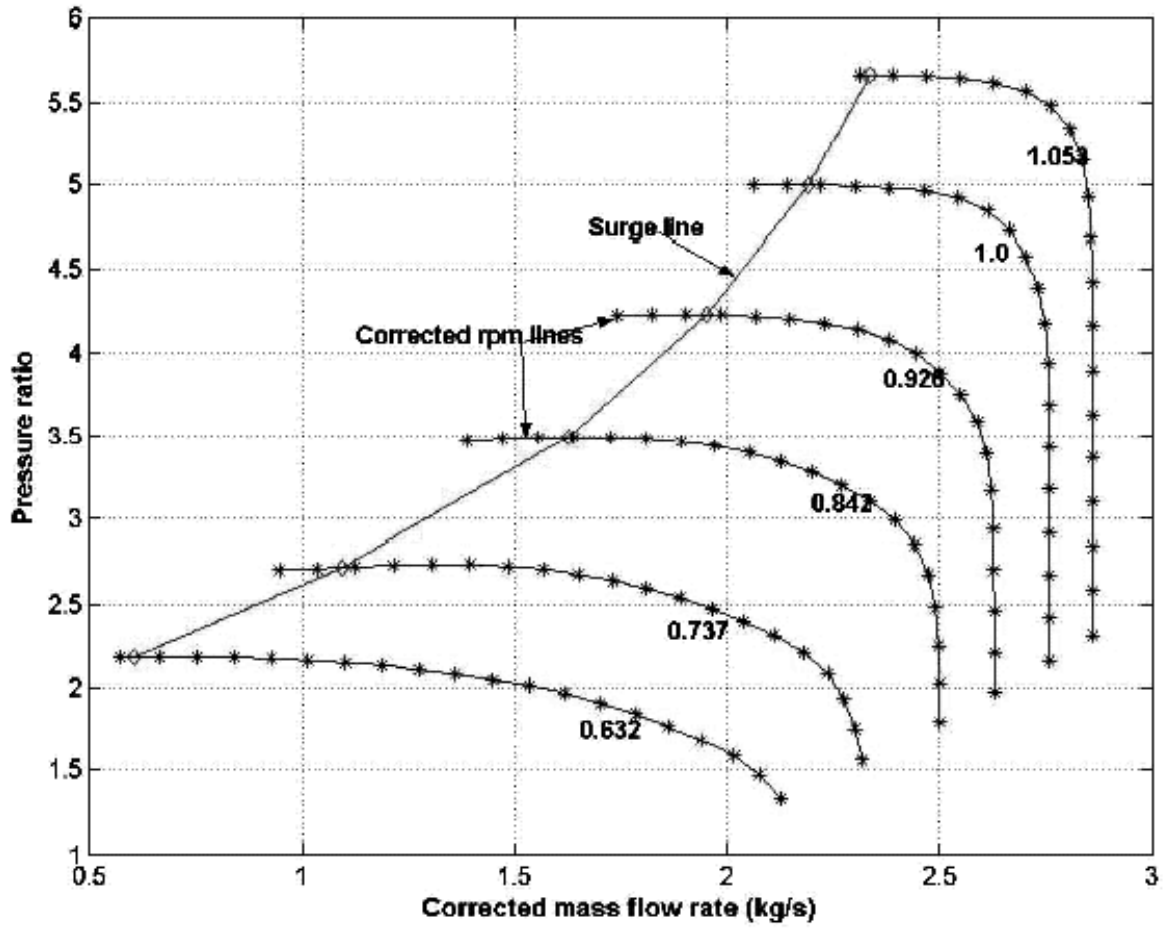


Figure 12 (a)

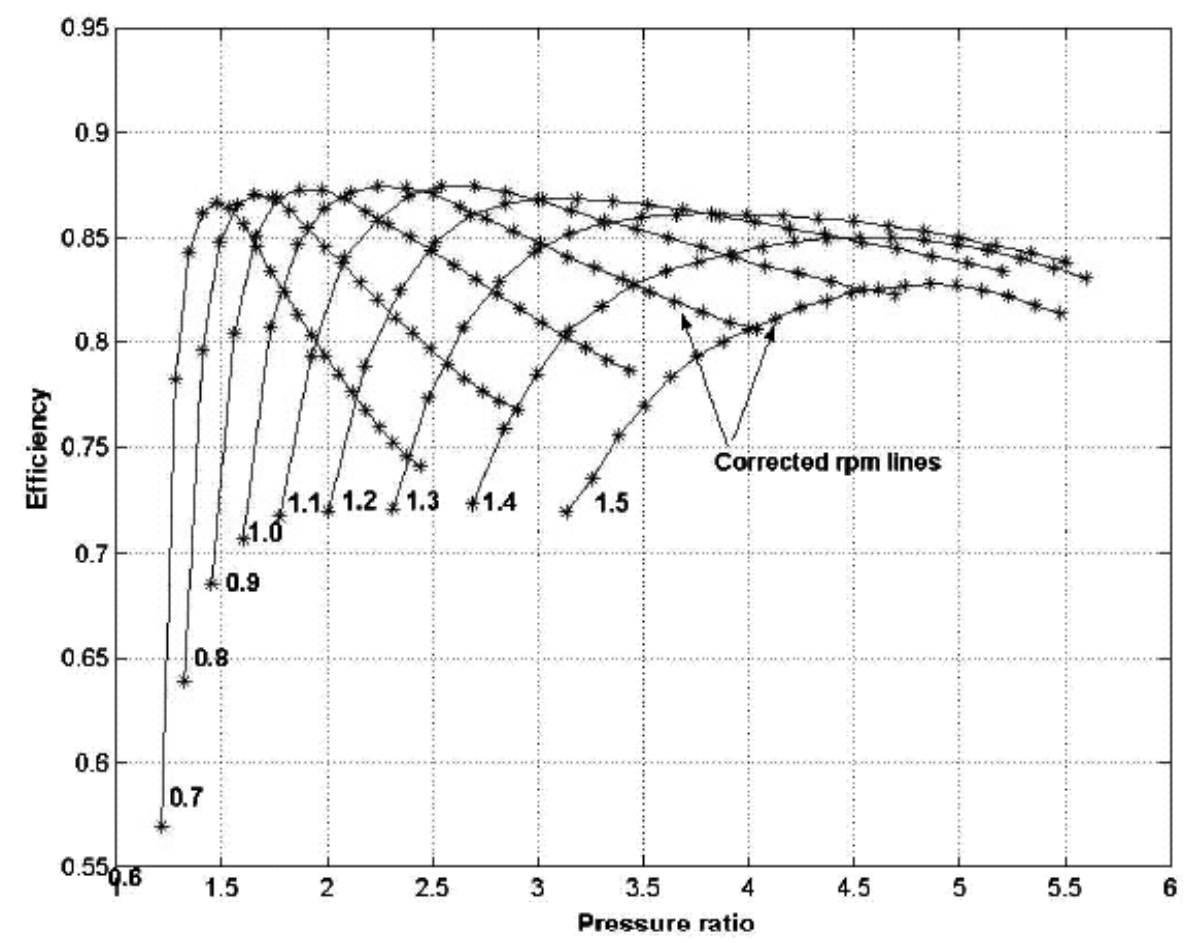

Figure 12 (b)

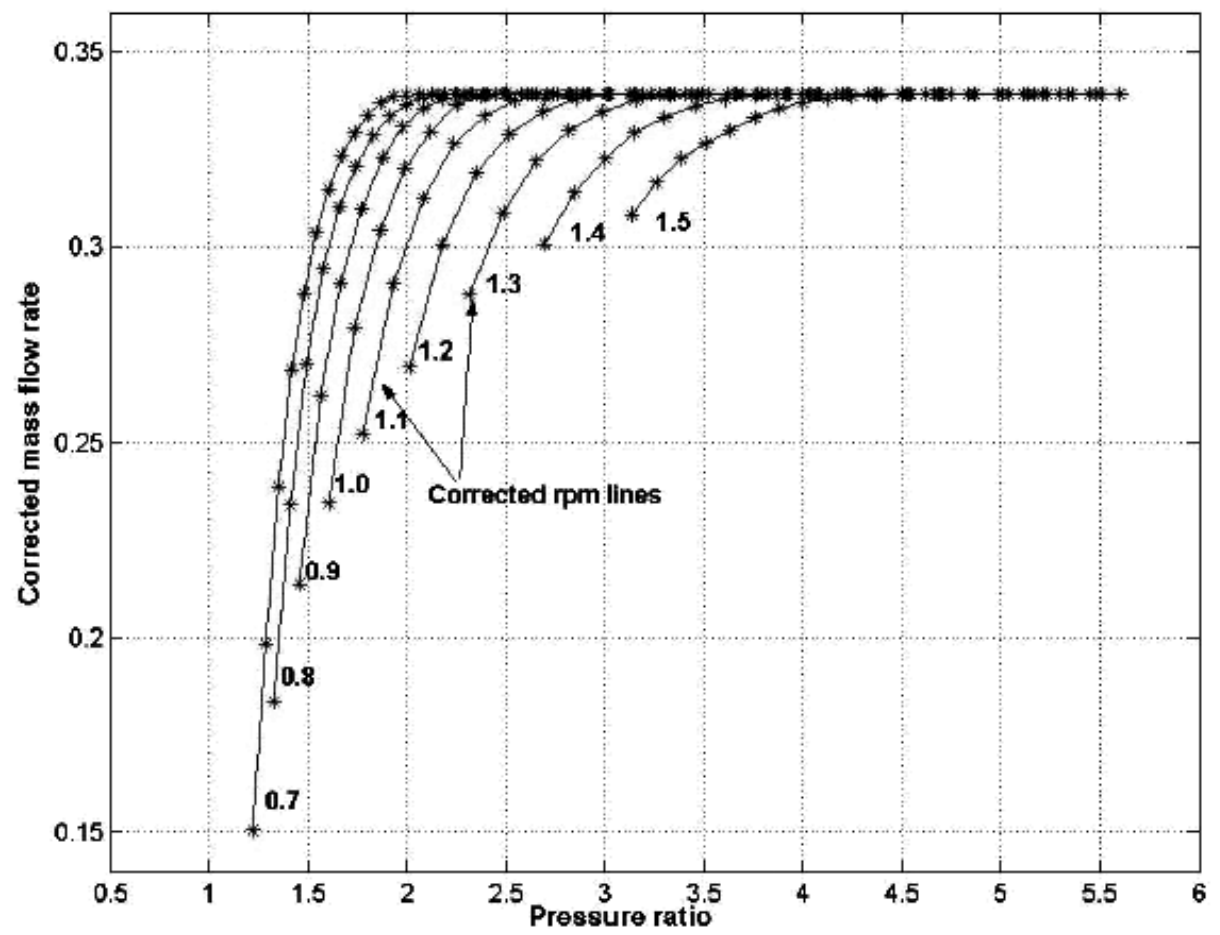


Figure 13

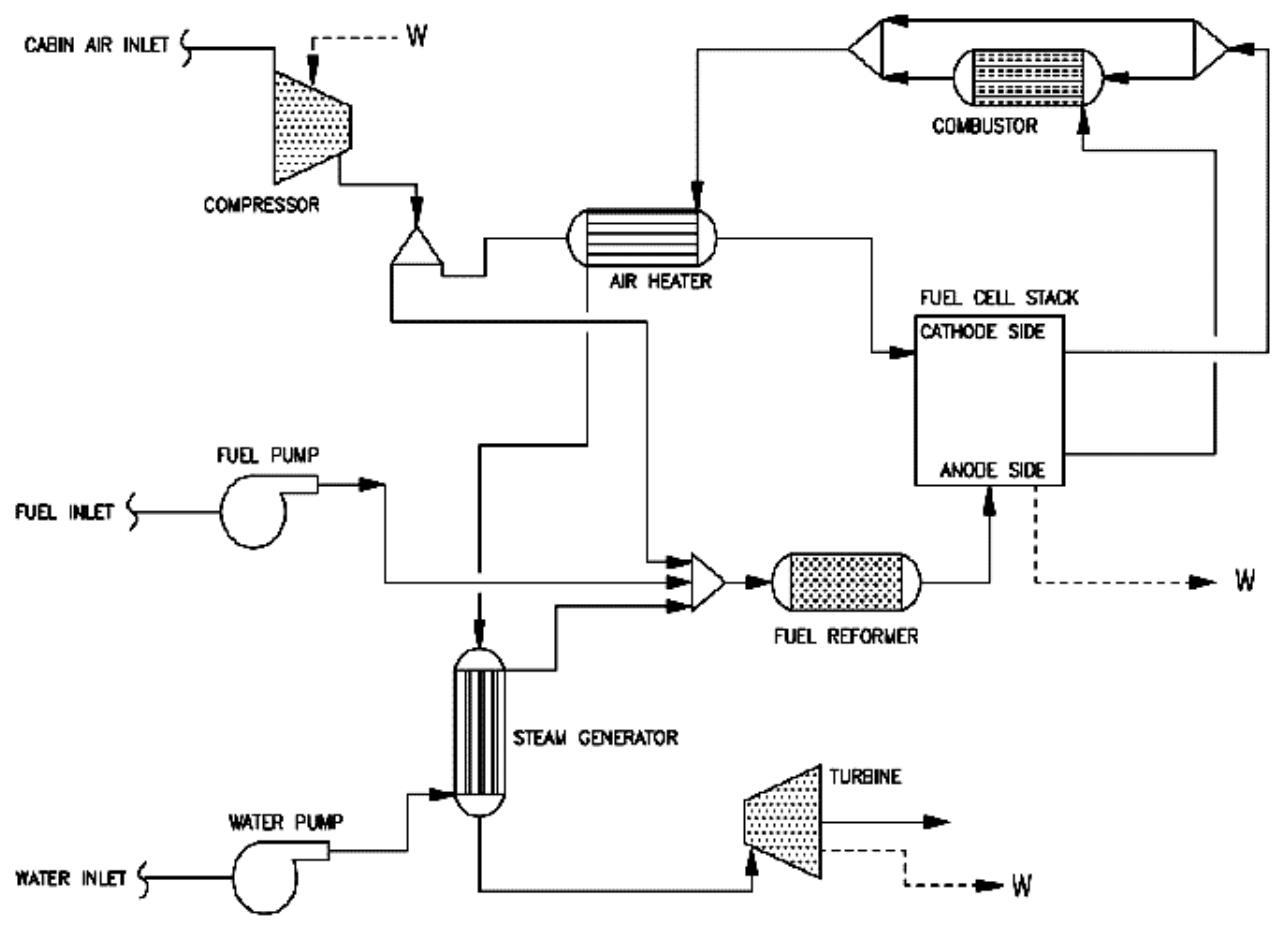

